\title{
Stik civilizacij Zgodovina interpretacij keltskega nakita iz Isthmije
}

\author{
Boris Kavur \\ UP FHŠ, Oddelek za arheologijo in dediščino ter Inštitut za arheologijo in dediščino \\ boris.kavur@upr.si
}

\section{Uvod}

Pričujoči prispevek je bolj zgodovinska kot arheološka razprava, ki prikazuje, kako so raziskovalci $\mathrm{v}$ desetletjih analiz in omemb izjemnih arheoloških najdb svoje interpretacije raje prilagodili interpretacijam zgodovinskih virov, kot pa da bi poskušali pojasniti arheološke podatke. Od odkritja dalje so keltske nanogvice, odkrite v bližini Pozejdonovega templja v grški Isthmiji, raje povezovali $\mathrm{z} v$ virih izpričano keltsko invazijo proti Delfom, kot pa, da bi poskušali interpretirati starost arheološkega konteksta. Slednji je starejši in resno maje temelje, na katerih stoji sistematika interpretacij kronologije mlajše železnodobne Evrope. Posledično je članek tako pregled razprav o interpretaciji kot tudi ilustracija obupnih poskusov vzdrževanja razlag znotraj zgodovinske cone udobja.

Srednjeevropski Kelti so se na začetku 4. stoletja pr. n. št. vse pogosteje pojavljali v zgodovinskih konfliktih med velesilami Sredozemlja. V okviru udejanjenja svoje imperialne politike je v letih 369-368 pr. n. št. sirakuški tiran Dionizij Starejši poslal keltske najemnike na pomoč Šparti v njenih spopadih proti Tebam. Šlo je za na severu Apeninskega polotoka novačene Kelte, ki so kmalu po osvojitvi Rima že delovali kot sirakuški plačanci v pohodih proti Krotonu in Lokriju (Bouzek 2002, 55; Szabó 1991, 333).

$\mathrm{Na}$ osrednjem Balkanu pa lahko s keltsko prisotnostjo računamo že od poraza in pregona Ardiejcev v letih $359 / 358$ pr. n. št., kot je to navedel Teopomp (Zaninović 2003, 278; Šašel Kos 2005, 168-70), zagotovo pa v času 
pohoda Aleksandra Velikega proti Tribalom leta 335 pr. n. št., ko je, kot poroča Arijan, slednji sprejel keltsko poslanstvo (Papazoglu 2007, 210-11; Theodossiev 2000, 80-82; 2005, 85; Džino 2007, 56). Ti stiki so bili najverjetneje trenutki direktnih stikov odličnikov iz najvišjega razreda vojaško-politične keltske aristokracije $\mathrm{z}$ aristokracijo ter diplomacijo makedonske države oziroma širšega grškega sveta; sveta, ki je zanje začel uporabljati naziv Galatai, ki naj bi bil izpeljanka iz keltske besede Galos, ki naj bi označevala hrabrega bojevnika (Bridgman 2004/2005, 157; Freeman 1993, 148-52).

Ponovno Kelti stopijo na prizorišče v času po smrti Aleksandra Velikega, predvsem pa po razpadu helespontskega Lizimahovega kraljestva leta 281 pr. n. št., ko se zaradi pomanjkanja kontrole ter vakuuma moči odpre pot proti jugu. Sedaj nastopijo na egejsko prizorišče kot bojeviti vsiljivci, kot največja katastrofa, ki je prizadela grški svet po perzijskih vojnah (Galiniki 2014). Makedonski kralj pade v bitki ter tokrat se prebijejo skozi Termopile. Sedaj so zapisi o njih drugačni in antični viri grški upor hitro opisujejo kot odmev perzijske invazije izpred dveh stoletij (Scott 2014, 170), prav tako pa je pri tem potrebno opozoriti na dejstvo, da je prav ekspedicija proti Delfom prvi primer opisa keltske migracije v literarni oziroma zgodovinski tradiciji (Mitchell 2001, 13). Hkrati pa se oblikuje literarni žanr, ki keltsko ekspanzijo opisuje kot militantni podvig Männerbunda s podjetniškim duhom ter posebnim vrednotenjem svobode. Izzivalna je misel, da je bil pojem (in ideja) »svobode" postavljen(a) na piedestal kot eksplicitna vrednota prav zaradi smiselne kontradistinkcije institucije sužnjelastništva v Sredozemlju (Taylor 2001, 39). Na drugi strani pa bi lahko keltske bojevnike predstavili kot nasprotje vojakom urbanega Sredozemlja - slednji so opravljali zadane naloge, prvi pa so imeli možnost izbire, pri čemer se niso odločali zgolj o svojih dejanjih, ampak so si lahko izbirali tudi svoje pokrovitelje oziroma zaveznike. Posledično jih je vezala obligacija do pokroviteljev oziroma individualnih poglavarjev in njihov status je bil definiran s temi odnosi. Prav tako pa je bil odvisen od individualne spretnosti, bojevitosti in časti $\mathrm{v}$ odnosu $\mathrm{z}$ drugimi člani bojevniške skupine. Velikokrat so delovali $v$ nasprotju $\mathrm{z}$ interesi večje skupine in sledili svojim lastnim oziroma interesom svojega voditelja, ki je lahko bil v kompeticiji za prestiž s podobnimi skupinami (Rawlings 1996, 81-82).

Vendar pa je bila velika večina antičnih pisnih virov, ki pričajo o tem nemirnem obdobju, napisana veliko kasneje, v času, ko so udeleženci pomrli, spomini zbledeli, ko so se spomeniki okrušili in votivi izgubili. Prav zaradi tega so toliko bolj dragoceni tisti neposredni arheološki viri, ki nam 
lahko ponazorijo dolgo zgodovino kulturnih in ekonomskih stikov med prazgodovinsko Evropo in kulturami vzhodnega Sredozemlja.

\section{Panhelenska Isthmija}

Dobrih 200 metrov jugozahodno od Pozejdonovega svetišča v Isthmiji, na področju, posvečenem Demetri, je nekdanji lastnik zemljišča ob zemeljskih delih odkril ostanke vodnjaka, ki ga je začel poglabljati ter uporabljati. Leta 1953 je z izkopom dosegel njegovo dno ter pri tem odkril skupno najdbo manjšega števila keramičnih posod (skyphoiodni krater s črnim premazom, korintski skyphos, čašo, tri miniaturne sklede, pet enostavnih ročk, tri oljenke in figuro iz terakote) ter dve bronasti orehasti nanogvici. $\mathrm{Na}$ skyphoidnem kraterju je bilo odkrito posvetilo, ki ga je Demetri namenila Sopha, ženska, glede na strukturo napisa govoreč dorski dialekt grškega jezika (Caskey 1960, 168, 172). Najzanimivejšo najdbo $z$ dna vodnjaka vsekakor predstavljata dve orehasti nanogvici, za kateri je že Caskey ustrezno ugotovil, da sta tujki v grškem svetu, ki izvirata iz latenskega kulturnega prostora. Šlo je za gladki orehasti nanogvici z osmimi votlimi odebelitva$\mathrm{mi}$, ki so visoke približno 4 centimetre ter s črto omejenimi sedlastimi prehodi med odebelitvami. Notranji premer obroča znaša 7 do $7,5 \mathrm{~cm}$, kar nam omogoča, da zaradi njihove velikosti govorimo o nanogvicah. Izdelani sta bili iz dveh delov, pri čemer telo predstavlja 6 odebelitev, na zapiralnem delu pa se nahajata še dve.

V objavi je Caskey opozoril, da se podoben nakit pogosto nahaja v grobovih na vzhodu keltskega sveta ter ga lahko datiramo v stopnjo Lt C oziroma v čas, kot je menil, od 3. do 1. stoletja pr. n. št. Kljub temu se je ogradil od interpretacije kronologije oziroma vprašanja starosti, saj je opozoril, da večina keramičnih predmetov izvira iz časa od 350 do 300 pr. n. št., nanogvici pa naj bi bili po sprejeti srednjeevropski kronologiji za srednjelatensko obdobje mlajši. Za rešitev zapleta je predlagal več možnosti - da so predmeti padli v vodnjak v različnih časih ali pa da so bili skupaj shranjeni dalj časa, preden so bili končno skupaj zavrženi. Opozoril je tudi na nenavadno sestavo skupka. Upoštevajoč napis gre očitno, vsaj pri luksuzni posodi, za posvetilo boginji. Taki predmeti se navadno odkrijejo v vodnjakih le v primeru nesreč ali pa prepolnosti templjev, ko se zavrže stare votive. V odkritem primeru pa je število najdb, ki bi jih lahko interpretirali kot čiščenje starih votivov, skromno, predvsem pa variabilno - skupek je sestavljen iz redkih luksuznih ter predvsem večine popolnoma vsakdanjih uporabnih keramičnih predmetov (Caskey 1960, 176). 
Kmalu po objavi se je najdbi posvetil Krämer (1961), pri čemer je ponovno ocenil nekatere interpretacije Caskeya in se osredotočil predvsem na datacije ter prepoznavo teritorialnega izvora orehastega nakita. V okviru relativne kronologije je opozoril, da moda nošenja orehastega nakita označuje prav pozno obdobje stopnje Lt B na Bavarskem (Krämer 1962, 307, Abb. 1). Menil je, da je najverjetnejša Caskeyeva trditev, da gre pri depoju za predmete, ki so bili zavrženi ob čiščenju svetišča, prav tako pa je opozoril na vrče, ki naj bi po njegovem mnenju kazali na čisto funkcionalno uporabo vodnjaka (Krämer 1961, 33). Pri interpretaciji starosti je povzel datacijo keramike v konec 4. stoletja in izpeljal trditev, da ne gre za zaprto najdbo oziroma so bili predmeti različnih starosti nekaj časa skupaj hranjeni v svetišču ter šele nato skupaj odvrženi v vodnjak (Krämer 1961, 37).
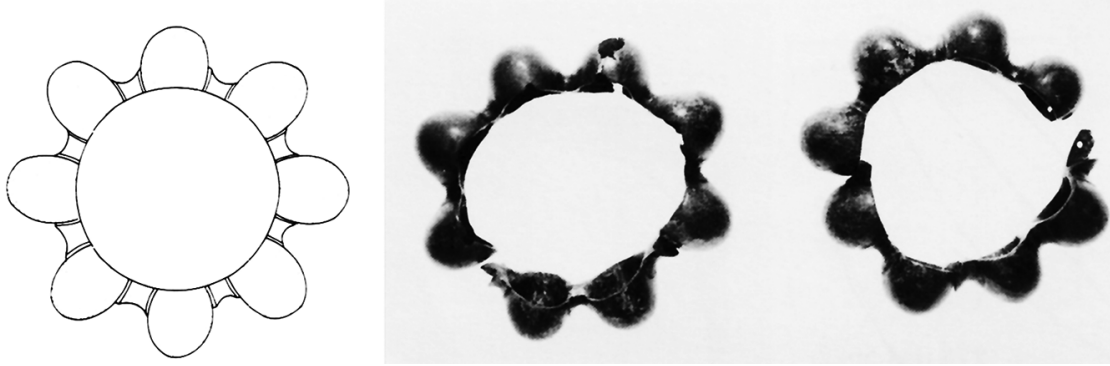

Slika i. Prva nanogvica iz Isthmije (povzeto po Raubitschek 1998, Plate 4I, 267A)

Za nanogvici je domneval, da sta prišli v Grčijo skupaj s svojo nosilko, ki jo je vključil v keltske skupine, ki so »z ženami in otroci pod vodstvom njihovih knezov v iskanju novih področij za naselitev prodrle proti Trakiji in Makedoniji« (Krämer 1961, 38). Tako je, da bi lahko argumentiral prisotnost ženskega nakitnega elementa, zgodovinski dogodek plenilskega vojaškega vdora proti Delfom preoblikoval v selitev celotne skupnosti v iskanju novega prostora poselitve. Zdelo se mu je, da bi bilo prav zaradi bližine Delfov, kjer je prišlo do preobrata v keltski invaziji, najdbo smiselno povezovati prav s slednjo. Pripomnil pa je tudi, da se moramo pri primerjavi datacije najdbe in sprejete, domnevno mlajše, kronološke pozicije orehastih zapestnic v osredji Evropi zavedati, da datacije slednjih stojijo na »šibkih nogah« (Krämer 1961, 38). Pri kartiranju orehastega nakita je opozoril na njegovo vzhodno razširjenost (Krämer 1961, 36-40, Abb. 1; 2) oziroma dejstvo, da se tudi znotraj prostora celotne distribucije orehastega nakita oblike $\mathrm{z}$ več kot 6 odebelitvami koncentrirajo v vzhodnem delu. Slednje so po- 
goste predvsem na dveh področjih s starejše- in srednjelatenskimi grobišči - ob južno-bavarskem toku Donave ter na severnem Češkem. Območji naj bi se po njegovem mnenju po materialni kulturi razlikovali od sosednjega zgornjega porečja Rena na eni ter Karpatske kotline na drugi strani. Na podlagi prostorske interpretacije je domneval, da so kontakti potekali ob Donavi ter da sta primerka, odkrita v Isthmiji, najverjetneje po Donavskem koridorju tudi prispela v Grčijo. Kljub vsemu pa je v zaključku razprave priznal, da si brez ogleda drugih primerkov najdb iz Isthmije ne bi upal pripisati področju bavarskega dela porečja Donave (Krämer 1961, 40-42).
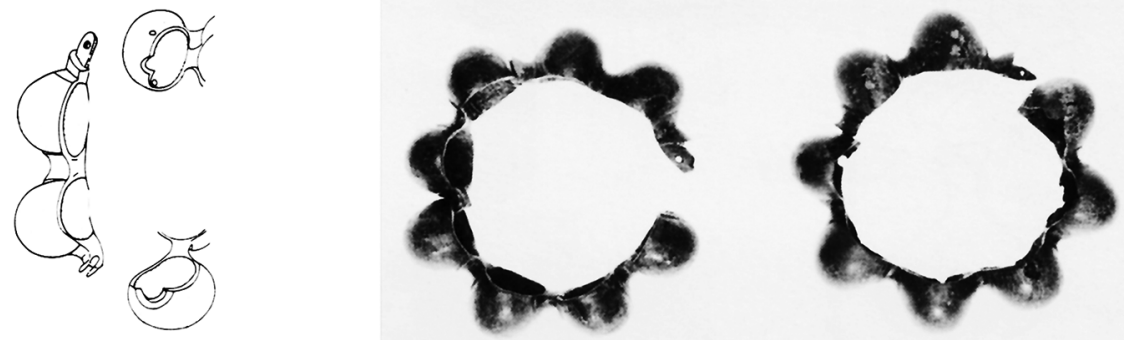

Slika 2. Druga nanogvica iz Isthmije (povzeto po Raubitschek 1998, Plate 41, 267B)

Ob koncu desetletja se je $\mathrm{z}$ vprašanjem izvora in datacije najdbe iz Isthmije ukvarjal Szabó (1968, 175-77), ki je najprej menil, da bi celotno najdbo lahko datirali $v$ 4. stoletje pr. n. št., le nekaj let kasneje pa je pri pregledu latenskih najdb na področju Grčije mnenje spremenil ter nanogvici iz Isthmije povezal z odpravo proti Delfom in ju posledično uvrstil v 3. stoletje pr. n. št. (Szabó 1971, 503; 1972). Za njim pa se je z vprašanjem orehastega nakita $v$ začetku sedemdesetih let intenzivno ukvarjal Schaaf, pri čemer je kot dodatek analize najdbe iz Male Azije (Schaaf 1972a) podal pregled načinov nošnje orehastega nakita v Evropi (Schaaf 1972b). Kljub dejstvu, da je bila večina najdb, ki jih je obravnaval, uvrščena v stopnjo Lt B2, je opozoril, da posamezne najdbe izvirajo tudi iz srednjelatenskih kontekstov. V pregledu je pokazal, da se način nošenja oziroma kombinacija in število kosov v posameznih regijah razlikujejo. $\mathrm{Na}$ Bavarskem nastopajo večinoma v paru in se nosijo na nogah, medtem ko se na področju Švice večinoma nahajajo posamezne najdbe, ki so bile nošene na rokah (Schaaf 1972b, 155). Prav tako je opozoril na največjo količino orehastega nakita na področju Češke, kjer so se večinoma nosile na enak način kot na Bavarskem (Schaaf 1972b, 155). 
Pri diskusiji o orehasti nanogvici iz okolice Finike v Turčiji pa je povzel Krämerjevo mnenje, da v primeru odkritja v Isthmiji ne moremo računati na zaprti kontekst in da bi ju morali povezati s keltskim vpadom proti Delfom iz leta 279 pr. n. št. Pri tem je navedel tudi mnenje M. Szaba, ki je ponudil možnost starejše datacije, ter opozoril, da so keltski plačanci bili prisotni v grškem svetu že pred letom 279 pr. n. št. (Schaaf 1972a, 95). Pri tem se je zavedal, da bi uvrstitev v 4. stoletje pr. n. št. nujno spremenila kronologijo srednjeevropske mlajše železne dobe. Vendar je poudaril, da lahko Szabovo hipotezo zavrže z naslednjim argumentom: par nanogvic predstavlja del ženske opreme, ki nikakor ne bi mogla biti povezana z moškimi plačanci iz obdobja pred pohodom na Delfe, kajti ti naj s sabo ne bi vodili svojih žena (Schaaff 1972a, 96-97).

Leto dni kasneje je pri pregledu latenskih najdb na področju Grčije Maier menil, da so Kelti vdrli na jug proti Delfom skupaj s svojimi ženami in otroci (Maier 1973, 461). Prav tako je zavrnil Szabovo hipotezo o keltskih plačancih iz sicilskih vojn v 4 . stoletju pr. n. št. ter menil, da je prav zaradi bližine Delfov nanogvici iz Isthmije verjetneje povezovati z omenjenim vdorom (Maier 1973, 477).

Ponovno sejekvprašanju orehastega nakitav začetku osemdesetih vrnil Szabó v svoji razpravi o začetku kovanja keltskih novcev v Karpatski kotlini. Opozoril je, da se je količina relevantnih podatkov od časa Krämerjeve analize močno povečala ter da lahko številne orehaste nanogvice s šestimi do desetimi odebelitvami, odkrite na področju Madžarske, Slovaške in Romunije, kronološko uvrstimo v prehodni horizont med stopnjama Lt B in Lt C (Szabó 1983, 45-46).

$\mathrm{V}$ osemdesetih pa je nanje pri revizijskih analizah najdb iz Isthmije opozorila tudi Isabelle Raubitschek. V kratkem povzetku zgodovine interpretacij je potrdila datacijo konteksta $\mathrm{v}$ 4. stoletje ter neustrezno povezovanje $\mathrm{z}$ dogodki leta 279 razlagala $\mathrm{z}$ zgodovinsko fascinacijo s pomembnim dogodkom, ki je zavedla številne avtorje (Raubitschek 1986, 40). Menila je, da je veliko verjetneje, da sta najdbi del bojnega plena, ki ga je po zmagi nad Kartažani pri reki Crimisus na Siciliji v Pozejdonov tempelj poslal Timoleon. Zgodovinski viri omenjajo, da so se v kartažanski vojski nahajali tudi keltski najemniki, ki so jih verjetno spremljale tudi njihove žene (Raubitschek 1986, 41). Žal pa je v zaključku svoje interpretacije spet nekoliko zapletla razlago - zaključila je, da sta nanogvici najverjetneje votivna darova iz druge polovice 4. stoletja pr. n. št., ki pa sta bila brez dvoma izdelana v osrčju keltskega sveta v podonavskem bazenu (Raubitschek 1986, 43). 
Nazadnje se je temi posvetil tudi Megaw. Pri pregledu najdb keltskega izvora izven latenskega kulturnega kroga na Balkanu je sicer povzel argumente Szaba, ki je v svojih zgodnjih delih v skladu z datacijo keramike iz vodnjaka videl možnost, da je najdba pripadala plačancu, vključenem v vojsko korintskega junaka Timoleona, oziroma plačancu Kasandra (Megaw 2004, 97), vendar jih je zavrnil $\mathrm{z}$ argumentom, da glede na pregled novih najdb s področja osrednje in vzhodne Evrope ne moremo mimo Krämerjeve datacije orehastega nakita v Lt B2/C1 (Megaw 2004, 97), kar pa bi moralo biti po konservativnem datiranju mlajše.

$\mathrm{V}$ širši kontekst, kjer je s primerjavo horizontov posameznih dobro objavljenih grobišč ustvaril relativno kronološke horizonte, je orehast nakit ob koncu osemdesetih umestil Rupert Gebhard. Prav tako slednji predstavlja enega izmed poglavitnih elementov, ki povezujejo prostor osrednje s prostorom vzhodne Evrope, svoj vrhunec uporabe pa doseže v horizontu 5, v katerem se pojavljajo številni elementi, ki kažejo na intenzivne kontakte s helenističnim svetom. Ključni problem Gebhardove sheme predstavljajo navezave horizontov na kontekste, ki jim lahko določimo absolutni kronološki okvir - uporabil je grob iz Ceretola, najdbo iz Isthmije, depo iz Egyházasdeneglega ter depo iz Ošanićev (Gebhard 1989, 108-9, 120, 122), pri čemer je najdbo orehastih zapestnic iz Isthmije "z veliko verjetnostjo « povezal s keltskim vpadom proti Delfom leta 279 pr. n. št. (Gebhard 1989, 122).

V zadnjem desetletju sta Krämerjevo retoriko sprejela tudi Rieckhoff in Biel, ki sta za poljudnoznanstveni prikaz obsega keltskih migracij, za katere sta trdila, da jih lahko opazujemo predvsem na podlagi posameznih oblik nespremenjenega ženskega nakita, uporabila karto z distribucijo orehastih nanogvic, označenih kot bavarskih, in seveda pripomnila, da najdbo iz Isthmije lahko povezujemo s keltskim vdorom iz leta 279 pr. n. št. (Rieckhoff in Biel 2001, 58). Na najdbo iz Isthmije se je v svojem teoretičnem pregledu retorike migracionizma $\mathrm{v}$ železnodobni arheologiji ozrl tudi Kaenel. Ločil je interpretacije od dejstev - na eni strani je opozoril na zgodovino njene interpretacije, na prvotno hipotezo o njenem izvoru ter predvsem na diktaturo historičnega vira $v$ njeni interpretaciji, ki se veže na keltsko odpravo proti jugu. Na drugi strani pa je povzel, da gre za izolirano najdbo, ki sodi v žensko sfero ter jo lahko, ali pa ne, povežemo z vojaškim pohodom (Kaenel 2007, 392).

Za zaokrožitev argumentov je potrebno na konec uvrstiti ne najnovejšo objavo vseh kovinskih predmetov iz kompleksa Pozejdonovega svetišča 
$\mathrm{v}$ Isthmiji, kjer je I. Raubitschek kratko povzela zgodovino razprav in ponovila datacijo keramičnih posod v tretjo četrtino 4. stoletja pr. n. št. Pod vplivom zgodovine interpretacij orehastih nanogvic tako datacijo konteksta raztegne na čas od tretje četrtine 4. do začetka 3. stoletja pr. n. št., pri čemer opomni, da je manj verjetno najdbo povezovati z vdorom proti Delfom, saj naj bi se preživeli ubežniki iz Brennusove katastrofalno zaključene odprave umikali skozi Termopile (Raubitschek 1998, 70, Pl. 41, 267A-B).

\section{Orehast nakit Keltov}

Za osvetlitev problema obravnave orehastega nakita $\mathrm{v}$ zvezi $\mathrm{z}$ interpretacijo najdbe iz Isthmije se moramo vrniti na začetek razprave. Kot prostorsko informativno distribucijo najdb je Krämer kartiral orehast nakit oziroma orehast nakit $s$ do 10 odebelitvami in 2 odebelitvama na zapiralki. Prav tako je prikazal nekatere identične najdbe $\mathrm{z}$ bavarskega dela doline Donave ter na koncu dodal seznam orehastega nakita s 6 do 10 odebelitvami s področja Bavarske, Avstrije, Češke, Moravske, Madžarske in Jugoslavije. Kot glavni kriterij za uvrstitev je izbral tip zaklepa oziroma zapiralko $\mathrm{z}$ dvema odebeljenima členoma ter zbral vse primerke $s$ do 10 odebelitvami, pri katerih je lahko na reprodukcijah prepoznal obliko šarnirja (Krämer 1961, 40-42). S to odločitvijo je povečal število kartiranih najdb, vendar je pri tem dodal številne kose, ki zaradi svoje oblike pravzaprav niso relevantne paralele. Njegova izbira kriterijev primerjave je tako ustvarila serijo težav - kot glavni kriterij izbire je vzel obliko zaklepa oziroma prisotnost zaklepa $\mathrm{z}$ dvema odebelitvama, hkrati pa je skupaj obravnaval ves orehast nakit $\mathrm{s} 6$ do 10 odebelitvami. Čeprav je združil primerke $\mathrm{z}$ različnim številom odebelitev, ni kartiral slabše reproduciranih oziroma poškodovanih in razlomljenih primerkov. Tako bi bilo ustrezneje, da bi kot direktne paralele z njegovega seznama upoštevali zgolj posamezne najdbe na Bavarskem, Češkem, Avstriji in na Madžarskem (Krämer 1961, 41-42). Kljub dejstvu, da je upošteval ravnokar izdano monografijo J. Filipa, na seznam ni uvrstil upodobljenega primerka iz Libkovic, ki je po obliki z osmimi odebelitvami identičen najdbi iz Isthmije (Filip 1956, Tab. XXX, 4). Njegovi odločitvi je najbrž botrovalo dejstvo, da na reproducirani fotografiji ni mogel rekonstruirati sistema zaklepa oz. razmerja med številom odebelitev. Na drugi strani pa je iz iste publikacije na seznam uvrstil primer iz Hranic, kjer je prepoznaven sistem zaklepa in viden tudi sedlast okras (Filip 1956, Tab. LX, 5), ter kos s sedmimi odebelitvami iz Radonic (Píč 1902, Tab. XIII, 19). $\mathrm{Na}$ seznam je uvrstil tudi kosa $\mathrm{z}$ osmimi odebelitvami iz Velkih Horešovic 
(Píč 1902, Tab. XIX, 3, 4) ter najdbo s sedmimi odebelitvami iz Kšelyja (Píč 1902, Tab. XXI, 6; Filip 1956, tab. LVII, 4), ne pa kosov, ki so bili preveč prepereli oziroma fragmentirani - npr. Libochovany (Filip 1956, Tab. XXV, 13), Košik, (Filip 1956, Tab. LII), Mistřrina (Filip 1956, Tab. LXXXV, 1) in iz Hornega Jatova (Benadik, Vlček in Ambros 1957, Taf. V, 2). Nadalje, uvrstil je kos s sedmimi odebelitvami in zaklepom $z$ dvema odebelitvama iz Libčevesa (Filip 1956, Tab. XXVIII, 6), ni pa uvrstil kosa z osmimi odebelitvami, na katerem se ne da rekonstruirati zaklepa $\mathrm{z}$ istega najdišča (Píč 1902, Tab. XXV, 12). Čeprav je prepoznavno, da primerek tvorita dve polovici s štirimi odebelitvami, je na seznam uvrstil kos iz groba v Pteníju na Moravskem (Filip 1956 CXI, 9; Čižmářová 2004, 291), ne pa najdbe s sedmimi odebelitvami iz Barsa na Madžarskem, ki po obliki zaklepa sicer ustreza njegovim kriterijem (Hunyady 1942, Tab. XXXI, 2). Prav tako na seznam ni uvrstil primerkov s sedmimi odebelitvami in $\mathrm{z}$ različnimi oblikami zaklepov iz Čejkovic (Filip 1956, Tab. XLVIII, 11, 12) in iz Hostomic (Filip 1956, Tab. XXXIII, 10, 11). Ob upoštevanju vseh primerljivih orehastih nanogvic iz Filipove publikacije, ki jo je Krämer poznal, bi se v času pisanja prispevka distribucija primerljivih najdb očitno prevesila na češko stran. Trend pa se je nadaljeval tudi v naslednjih letih in desetletjih.

Od poznih sedemdesetih let dalje se je s kataloškimi objavami številnih grobišč na Češkem in na Bavarskem povečalo število poznanih, najdbi iz Isthmije bolj ali manj podobnih primerov. Nanogvice so bile odkrite na grobiščih Jenišův Újezd (Waldhauser 1978, Taf. 27, 10911-12; Taf. 31, 8919-20), Libčeves (Budinský 1994, Abb. X, 13) in Libkovice (Kruta 1975, 146, 288, Fig. 6o, 3; Celtes 2006, 319, 18/1d; Filip 1956, Tab. XXX, 4) na Češkem; v Chotinu na Slovaškem (Ratimorská 1981, 45-46, Tab. XVII, A1) ter na Lispestentadorján-Öreghegy (Horváth 1987, 84, 153, Pl. XIV, 8, 9) in Szomód-Kenderhegy na Madžarskem (Vadász 1987, 231-33, 242, Pl. III, 10, 12). Kramer je kasneje za področje Bavarske objavil katalog grobov s kosi, ki jih je že navedel leta 1971, ter dodal nekaj novih, pri čemer je objavil še nekaj kosov z osmimi odebelitvami in drugačnim zaklepom - ErdingSiglfing (Krämer 1985, Taf. 40, 9-10) in Langengeisling (Krämer 1985, Taf. $46,1-2)$. Orehasta zapestnica $z$ osmimi odebelitvami, identična najdbi iz Isthmije, pa je bila objavljena tudi v izjemno bogatem grobu 149 na najdišču Münsingen-Rain (Hodson 1968, 138, Pl. 64, 405). Gre za edini grob v Švici, v katerem sta bili odkriti dve orehasti zapestnici, ki ju je pokojnica nosila na desni roki (Schaaf 1972b, 155). Orehasta nanogvica z 12 odebelitvami, s kaneluro na robu sedla ter $\mathrm{z}$ dvema členoma na zaporki je bila odkrita tudi $\mathrm{v}$ 
ženskem grobu 157 z istega najdišča (Martin-Kilcher 1973, 31, Abb. 8), ki pa kljub reprodukciji v besedilu sicer ni bil komentiran, je pa bil na tabeli uvrščen v stopnjo Lt B2 oziroma horizont L/P po Hodsonu (Martin-Kilcher 1973, 27, Abb. 2). Avtorica je že takrat jasno pokazala, da se navada nošenja asimetričnih nanogvic med posameznimi najdišči močno razlikuje, prav tako pa je navedla, da naj bi svoj vrhunec doživela ob koncu stopnje Lt B2 in počasi zamrla $v$ stopnji Lt C (Martin-Kilcher 1973, 27).

Vrstile pa so se tudi razprave, ki so precizirale starost in pojavljanje tovrstnega nakita - na madžarskem najdišču Ludas-Varjú-Dülő je bila orehasta nanogvica odkrita med ostalim v grobu 1282, ki je bil uvrščen v 5. horizont grobišča oziroma v konec stopnje Lt B (Szabó in Tankó 2006, 332-33, Fig. 5, 8). Orehaste nanogvice $\mathrm{z}$ osmimi odebelitvami nekoliko drugačnega tipa, $s$ tanjšo sedlasto povezavo, $z$ drugačnim zaklepom in $s$ kovinskim trakom na notranji strani so bile odkrite tudi v grobovih 124 in $126 \mathrm{z}$ najdišča Maňa na Slovaškem (Benadik 1983, 55-60, 129, 131, Taf. XLVI, 3-4; Taf. XLVIII, 1, 4), kjer jih lahko datiramo v pozno stopnjo Lt B. Za datiranje uporabe orehastega nakita na področju Romunije je pomembna najdba iz groba 108 z grobišča Pişcolt, kjer je bila zraven dveh orehastih nanogvic s 7 odebelitvami med drugimi pridatki odkrita tudi za starejše latensko obdobje značilna ovratnica s ploščicami (Németi 1992, Fig. 18, 9-11; Szabó 1983, Taf. XV, 5-6). Na drugi strani pa sta bili podobni nanogvici odkriti v skeletnem grobu številka 1 iz Dindeştija skupaj s fibulo srednje latenske sheme (Zirra 1971, 532-33, 545, Abb. 3, 11, Abb. 7, 1-2). Pri analizi kronologije grobov na grobišču Maňa na Slovaškem je Benadik grobove, ki so vsebovali orehast nakit, zaradi pogoste prisotnosti žičnatih fibul srednjelatenske sheme prav tako uvrstil v stopnjo Lt C1 (Benadik 1978, 4O7, Abb. 20). Primerki s šestimi odebelitvami z različnimi oblikami notranjih trakov in zaklepov so znani iz groba 564 iz Hornega Jatova (Benadik, Vlček in Ambros 1957, Taf. XIV, 2-3) in iz groba 1 z Dvorov nad Žitavou (Benadik, Vlček in Ambros 1957, Taf. XXVII, 3, 8), kjer jih na podlagi drugih pridatkov prav tako lahko datiramo v stopnjo Lt C1.

Poglaviten prispevek k sistematiki kronološkega razmišljanja na prostoru med osrednjo ter jugovzhodno Evropo je monumentalna razprava o steklenem nakitu iz Manchinga, ki jo je objavil Gebhard. Orehast nakit po njegovem mnenju predstavlja eno izmed poglavitnih poznih nakitnih oblik starejšega latenskega obdobja, uvrščenih v njegova horizonta 4 in 5 , ki se spreminja in razvija še v mlajšem, srednjelatenskem, horizontu 6. Pri tem je pokazal, da se spreminja tudi višina odebelitev gladkih orehastih pred- 
metov - v horizontu 5 so pri primerkih s sedmimi do devetimi odebelitvami te visoke manj kot $5 \mathrm{~cm}$ (navadno med 3,4 in 4,2 cm), v horizontu 6 pa so pri primerkih s šestimi do sedmimi odebelitvami višje od $5 \mathrm{~cm}$ (Gebhard 1989, 109-20). Zanj, tako kot za Ceretolo, enega izmed glavnih argumentov za datacijo horizonta 5 predstavlja prav najdba orehastih zapestnic iz Isthmije, ki jo je $» \mathrm{Z}$ veliko verjetnostjo " povezal s keltskim vpadom proti Delfom leta 279 pr. n. št. (Gebhard 1989, 122). Z razdelitvijo na kronološke horizonte, ki jih je absolutno datiral na podlagi starosti sredozemskih importov v keltskih kontekstih, je ustvaril tako konceptualni okvir za razumevanje stika civilizacij kot tudi kronološki okvir, iz katerega se večina raziskovalcev, ukvarjajočih se predvsem $\mathrm{z}$ lokalnimi kronološkimi proble$\mathrm{mi}$, še danes ne more izviti. Poglavitni problem njegovega modela nastopi prav na mestu datiranja konca starejšega in začetka srednjelatenskega obdobja, ki ga zaznamuje nadrealni zgodovinski diktat keltske invazije proti Delfom - predvsem pa interpretacija domnevnih posledic tega. Tako se situla iz Karaburme, ki bi bila v helenističnem kontekstu starejša od keltskega groba, v katerem je bila odkrita (Blečić Kavur in Kavur 2010), kot tudi nanogvice iz Isthmije, ki bi bile v keltskem svetu mlajše od vodnjaka, v katerem so bile odkrite (Kavur in Blečić Kavur 2018), znajdejo interpretativno vezane na zgodovinski dogodek, $\mathrm{s}$ katerim jih, $\mathrm{v}$ strogem arheološkem pogledu, sploh ne moremo povezati.

Po dolgem zatišju se je na začetku 21. stoletja predvsem s tehnologijo izdelave orehastega nakita v Karpatski kotlini ukvarjala A. Masse. Glede na velikost odebelitev in notranji premer je sklenila, da primerki s povprečnim premerom $4 \mathrm{krat} 5,5 \mathrm{~cm}$ in $\mathrm{z}$ višino odebelitev med 2 in $3 \mathrm{~cm}$ sodijo med zapestnice. Na drugi strani pa naj bi premer nanogvic povprečno meril 5 krat $8 \mathrm{~cm}$, z višino odebelitev, večjo od $3 \mathrm{~cm}$ (Masse in Szabó 2005, 214-15, Fig. 3; Masse 2007, 302). V analizi je zbrala podatke za 232 kosov orehastega nakita s področja Madžarske, od tega zgolj 89 kosov izvira iz dobro dokumentiranih grobov. Pri kartiranju jih je razdelila na zapestnice $\mathrm{z}$ več kot 4 odebelitvami, nanogvice $s 3$ ali 4 odebelitvami in nanogvice z več kot 4 odebelitvami. Dodala je tudi kategorijo nedoločljivih odlomkov (Masse in Szabó 2005, 216-20, Fig. 5; Masse 2007, 304-6, Fig. 4). Pri kronološkem pregledu oziroma kompilaciji mnenj različnih avtorjev od začetka osemdesetih let je pokazala, da lahko začetek uporabe orehastega nakita postavljamo v stopnjo Lt B2 in konec na konec stopnje Lt C1. Zgolj kratko pa se je pri debati o absolutni dataciji začetka uporabe orehastega nakita ozrla na nanogvici iz Isthmije (Masse in Szabó 2005, 220). 
Poleg vzorca orehastega nakita, ki ga je na področju Madžarske zbrala A. Masse, nam vpogled $\mathrm{v}$ novo količino dostopnih najdb nudijo tudi rezultati metalografskih analiz obročastega nakita na Češkem, kjer je bilo analiziranih kar 118 vzorcev, izvirajočih iz nakita s štirimi odebelitvami na telesu, ter dvema na zaporki in s sedlastimi prehodi (Sankot 2002, 342, Abb. 13). Predvsem pa je v sistematični pregled vsega obročastega nakita orehaste nanogvice s področja Slovaške uvrstil J. Bujna. Pokazal je zlasti na izjemno oblikovno variabilnost orehastega nakita, pri čemer je za osnovne kriterije analize za razliko od Krämerja vzel obliko, velikost ter število odebelitev. Pri vprašanju njihove kronologije je sprejel Gebhardovo mnenje in jih uvrstil v stopnjo Lt $\mathrm{B}_{2} \mathrm{~b}$ oziroma pri tipu $\mathrm{F}_{3}$ dopustil možnost trajanja do prehodnega horizonta Lt B2/C1. Pri tem izstopajo prav nanogvice podtipa F3A, ki imajo osem odebelitev in sedlast prehod, vendar jih na notranji strani povezuje trak ter so sestavljene iz dveh delov po štiri odebelitve (Bujna 2005, 47-57). Bujna je pri opisovanju tovrstnega nakita ustvaril vplivno delitev, ki so se je držali vsi avtorji v zadnjih dveh desetletjih. V svoji doktorski disertaciji M. Furman žal ni izkoristil interpretativnega potenciala nanogvic iz Isthmije in je posledično $\mathrm{v} v$ seh kasnejših objavah razvoja obročastega nakita in sprememb nakitnih garnitur uporabljal zgolj srednjeevropsko relativno kronologijo (Furman 2009; 2012; 2014). Podobno metodologijo je izbrala tudi N. B. Fábry, ki je pri svojih razpravah (s poudarkom na mlajših nanogvicah $\mathrm{s} 4$ in 3 odebelitvami) $\mathrm{v}$ relativno in absolutno kronološkem smislu obdržala Gebhardove okvire (Fábry 2012; 2016).

Če poskušamo povzeti kronologijo razprav, povezanih z odkritjem in interpretacijo nanogvic iz Isthmije, ter njihovo vlogo pri razpravah o kronologiji orehastega nakita (in mlajše železne dobe nasploh), lahko zaključimo, da so bila predvsem šestdeseta in sedemdeseta leta 20. stoletja obdobje, ko so avtorji najdbo poskušali razumeti kot primarni, ne zgolj arheološki, ampak tudi zgodovinski vir, vir, ki lahko pojasni kronologijo ter potek procesov kulturnih stikov. Naslednji dve desetletji so se v Evropi zgolj kopičile nove najdbe, ni pa bilo toliko poskusov vzpostavitve kronoloških mostov kot da se je evropska arheologija začela vedno bolj oddaljevati od helenskega in helenističnega sveta. Obdobje se je zaključilo z objavo kompleksnega poskusa sinhronizacije kronologij Gebharda, ki pa je v svojem jedru temeljila na nekaterih domnevah oziroma na nasilnem pripisovanju nekaterih starejših najdb iz zgodovinskih virov znanemu dogodku, ko so Kelti vdrli proti jugu v samo osrčje grškega sveta. Kronologija je v uporabi, pa ne zato, ker bi bila pravilna, ampak zato, ker je priročna, ostala do danes. Drugo 
programsko objavo je dobrih 15 let kasneje objavil Bujna, ki je natančno razdelal tipologijo oziroma sistematiko opisovanja obročastega nakita in odprl pot generaciji mlajših raziskovalcev, ki na področju dominira že več kot desetletje, oborožena z Gebhardovo kronologijo. Nekoliko pobalinsko sva pred skoraj desetletjem z Mitjo Guštinom objavila minimalistični kronološki pamflet (Kavur in Guštin 2011, 129-30), ki pa je ostal brez konkretnejših odzivov. V slednjem sva prav na osnovi najdbe nanogvic iz Isthmije predlagala radikalno revizijo kronologije konca starejšega in začetka srednjega latena, predvsem pa sva proces poskusila uskladiti z arheološko dokumentiranimi stiki civilizacij in ga oddaljiti iz zgodovinsko zapovedanih spopadov civilizacij.

Nazadnje lahko kot metaforo za nezmožnost odmika od interpretativnega diktata zgodovinskih virov vidimo v geslu Isthmia, ki ga je v Lexikon zur keltischen Archäologie napisal Szabó. V prvem odstavku je kontekst na osnovi »črepinj« keramike datiral v 4. stoletje pr. n. št. V drugem pa se je poklonil mnenju "poznavalcev« keltske arheologije in najdbo povezal s pohodom proti Delfom. Vse je zrelativiziral s trditvijo, da je najdba lahko tudi posledica prisotnosti keltskih plačancev, ki so se s svojimi ženami v prostoru nahajali pred in po letu 279, oziroma navedel, da antični viri omenjajo upor slednjih leta 265 pr. n. št. v Megari (Szabó 2012, 840-41). Gre pravzaprav za pristop, ki ga je uporabil v svojih poznih razpravah, kjer je vzporedno navajal več možnosti interpretacije, izpostavil kontradikcije med scenariji oziroma njihovimi kronološkimi posledicami, toda na koncu se ni opredelil za nobenega od njih (Szabó 2000; 2015).

Megarsko interpretacijo pa je prevzel od Krute (Kruta 2000, 687), ki je najdbe iz Isthmije poskušal, ne glede na kontekst in starost njihovega odkritja, čim bolj uskladiti s predpostavkami evropske kronologije. Pravzaprav lahko $\mathrm{v}$ delih starejše generacije raziskovalcev $\mathrm{v}$ zadnjih desetletjih vidimo velik razkorak $\mathrm{v}$ interpretacijah - na eni strani navajajo zgodovinske vire za zgodnjo keltsko prisotnost že v 4 . stoletju pr. $n$. št. v grškem svetu, na drugi strani pa najdbo iz Isthmije še vedno vežejo na ekspedicijo proti Delfom (Bouzek 2014, 225-26).

\section{Zaključek}

Poglavitne najdbe, s katerimi lahko stkemo zapleteno mrežo povezanih točk, ki pomenijo osnovo za usklajeno absolutno kronologijo, predstavljajo na eni strani najdbe predmetov keltske provenience oziroma latenske kulture $\mathrm{v}$ sredozemskih, $\mathrm{tj}$. egejskih kontekstih $\mathrm{z}$ absolutnimi datacijami. 
Vice versa, dopolnjujejo jih najdbe predmetov, izvirajočih iz egejskega sveta v latenskih kontekstih. Če je njihova absolutna kronološka pozicija lahko vedno manj predmet razprave, postaja njihova interpretacija vedno spornejša. Na obeh straneh velike ločnice - tako $\mathrm{v}$ prazgodovinskem evropskem kot tudi v klasičnem sredozemskem svetu - delujoči arheologi so te predmete tradicionalno interpretirali kot vojni plen ali najemniško plačilo (Szabó 1996, 21; Schönfelder 2007). Šele nedavno pa se je začelo razmišljati o diplomatskih darilih, ki so po ustaljenih trgovskih poteh povezovala družbene elite različnih skupnosti (Blečić Kavur in Kavur 2010; Kavur in Blečić Kavur 2018; Rustoiu in Egri 2010, 221). Toda, tovrstno razmišljanje je bilo izoblikovano že veliko prej - vendar spregledano. Že na začetku sedemdesetih je v članku o kulturnih kontaktih med madžarskim železnodobnim (keltskim) kulturnim področjem in grškim svetom izpostavila v zvezi s kantharosom iz Szoba I. Bognár-Kutzián (1971, 145). Presenečeno je opomnila, da kantharos, kot najlepši primer stikov med tema dvema svetovoma $\mathrm{v}$ desetletjih, ni vzpodbudil interesa ne madžarske niti mednarodne javnosti, ter nanizala tri ključna vprašanja, povezana s slednjim, na katera bi bilo potrebno čim prej odgovoriti. Zanimale so jo natančna datacija tega tipa posode, definicija delavnice, ki ga je izdelala oziroma njegov prototip, in seveda pot, po kateri je prišel iz egejskega prostora do kolena Donave. Navedla je nekaj grobov v Makedoniji in Trakiji, kjer so bili odkriti podobni kantharosi, izdelani iz srebra, in na osnovi njihovih kontekstov najdbo datirala $\mathrm{v}$ drugo polovico 4 . stoletja pr. n. št. ali v vsakem primeru v čas pred letom 300 pr. n. št. Še več, čeprav naj bi glede na keramiko druge najdbe sodile $\mathrm{v}$ drugo polovico 3. in prvo polovico 2. stoletja pr. $\mathrm{n}$. št., je menila, da tako dolgo zadrževanje $v$ obtoku ni verjetno. $S$ tem je tudi sklenila, da je datiranje prav bronastih kantharosov ključnega pomena za natančno absolutno datiranje latenske kulture Karpatskega bazena in centralne Evrope (Bognár-Kutzián 1971, 145-46). Kantharos iz Szoba ni bil edini primerek, pri katerem je prihajalo do kontradikcije med prazgodovinsko evropsko ter grško kronologijo. Zato se je navezala na najdbo nanogvic iz Isthmije tako, da je izpostavila vprašanje starosti konteksta njihovega odkritja, ki bi moralo biti starejše od 3. stoletja pr. n. št. S tem je celo pokazala, da ima srednjeevropska stopnja Lt $\mathrm{C}$ velike kronološke diskrepance. Domnevala je, da smo v karpatskem bazenu priča horizontu stikov med keltskim in grškim svetom, starejših od bajeslovnega pohoda proti Delfom (Bognár-Kutzián 1971, 146-47). 
$\mathrm{Na}$ tem mestu pa je primerno opozoriti na zmotno trditev I. Raubitschek, ki je pri obravnavi nanogvic iz Isthmije zapisala, da je bil podoben nakit odkrit tudi v Heraionu v Perachori (Raubitschek 1998, 70). V resnici pa je tam odkrita zapestnica drugačna. Gre za veliko starejši starejšeželeznodobni nakit, ki sodi, kot tudi večina drugih iz osrednje in zahodne Evrope izvirajočih najdb, odkritih v Heraionu, v čas stopnje Ha D1 (Verger 2003, 526-30). Prazgodovinske predmete, odkrite v panhelenskih svetiščih, moramo zato razumeti kot simbolična diplomatska darila, ki pa ne označujejo zgolj enosmernega toka blaga, ampak so del omrežij, v katera so bili, kot že stoletja pred tem, v 4. stoletju pr. n. št. vključeni Kelti. Poglavitno najdbo v klasičnem svetu, ki bi lahko omogočala vzpostavitev absolutne kronologije kulturnih kontaktov, predstavlja prav najdba dveh nanogvic iz Isthmije. Ta najdba nikakor ni osamljen primer, žal pa ima edina poznan zaprt arheološki kontekst, ki ji omogoča dobro datacijo/časovno umestitev.

Lahko sklepamo, da se predmeti helenistične umetniške obrti, izvirajoči predvsem iz makedonskih delavnic, v keltskem svetu nahajajo večinoma priloženi v grobove (Karaburma, Szob, Szabolc, Hurbanovo). Predmeti, izvirajoči iz latenskega kulturnega kroga, pa se izven slednjega nahajajo praviloma v ritualnih in/ali kultnih kontekstih (Dodona, Isthmia, Delos, Delfi), darovano orožje pa je upodobljeno v svetiščih (Delfi, Marathon) (Kavur in Blečić Kavur 2018). Toda kronološki pregled posameznih predmetov in pregled primerjalnega gradiva pokaže, da zgolj del navedenega lahko vežemo na razvpiti balkanski keltski pohod na Delfe in dogodke v naslednjih letih. Večina helenističnih predmetov, ki se nahajajo v keltskih grobovih, torej izvira iz časa tretje četrtine 4 . stoletja pr. n. št., dejansko iz časa največje kulturne in ekonomske ekspanzije na eni in najintenzivnejših diplomatskih stikov makedonske države z ljudstvi na drugi, severni, strani.

\section{Zahvala}

$\mathrm{V}$ največji meri se moram zahvaliti Martini Blečić Kavur za vse potrpljenje pri poslušanju skoraj desetletja in pol mojih monologov na to temo. Prav tako se zahvaljujem Mitji Guštinu za številne pogovore in komentarje na zgodnjo verzijo rokopisa ter Janu Kyseli, ki mi je omogočil, da sem ideje formuliral v seriji predavanj (ter pogovorov) na Karlovi Univerzi v Pragi.

Prispevek je nastal na podlagi raziskav, sofinanciranih iz projekta ARRS J6-6837 »Stik civilizacij«. 


\section{Literatura}

Benadik, B. 1978. »Keltisches Gräberfeld in Maňa.«Slovenská archeológia 26: 383-422.

Benadik. B. 1983. Maňa: Keltisches Gräberfeld. Nitra: Materialia Archaeologica Slovaca.

Benadik, B., E. Vlček in C. Ambros 1957. Keltské pohrebiská na juhozápadnom Slovensku. Bratislava: Fontes, Tom.

Blečić Kavur, M., in B. Kavur 2010. "Grob 22 iz beogradske nekropole Karaburma: retrospektiva i perspektiva.« Starinar 60: 57-84.

Bognár-Kutzián, I. 1971. »Prehistoric Relations between Hungary and the Balkans." V L'ethnogenese de peuples balkaniques: Symposium international sur l'ethnogenese des peuples Balkaniques Plovdiv, 23-28 avril 1968, 139224. Sofija: Academie Bulgare des Sciences, Institut d'etudes Balkaniques.

Bouzek, J. 2002. "Die Bronzelekithos des Typus Talcott aus Hurbanovo und andere vorrömische mediterrane Bronzegefäße in der Slowakei.« Anodos: Studies of the Ancient World 2: 53-57.

Bouzek, J. 2014. »The Celtic Mercenary Reconsidered.«V Celtic Art in Europe: Making Connections - Essays in Honour of Vincent Megaw on his 8oth Birthday, ur. C. Gosden, S. Crawford in K. Ulmschneider, 223-33. Oxford; Philadelphia, PA: Oxbow Books.

Bridgman, T. P. 2004/2005. »Keltoi, Galatai, Galli: Were They All One People?« Proceedings of the Harvard Celtic Colloquium 24/25: 155-62.

Budinský, P. 1994. Keltské kostrové hroby $z$ litoměřicka a $z$ lounska $v$ archeologické sbirce teplického muzea. (fond Teplice). Archeologický výzkum v severních Čechách 23. Teplice: Regionální muzeum Teplice.

Bujna, J. 2005. Kruhovýšperk z laténskych ženských hrobov na Slovensku. Nitra: Univerzita Konštantína Filozofa, Archeologický ústav SAV.

Caskey, J. L. 1960. »Objects from a Well at Isthmia.« Hesperia 29 (2): 168-76.

Celtes. 2006. Celtes. Belges, Bö̈ens, Rèmes, Volques... Mariemont: Exhibitions.

Čižmářová, J. 2004. Encyklopedie Keltů na Moravě a ve Slezsku. Praga: Libri.

Džino, D. 2007. "The Celts in Illyricum - Whoever They May Be: The Hybridization and Construction of Identities in Southeastern Europe in the Fourth and Third Centuries BC." Opuscula Archaeologica 31 (1): 93-112.

Fábry, N. B. 2012. "Les anneaux à oves creux de la nécropole laténiene de Ludas.«V La nécropole celtique à Ludas-Varjú-Dülő, ur. M. Szabó, 181-87. Budimpešta: Harmattan. 
Fábry, N. B. 2016. »Gli anelli da caviglia lateniani in area ungherese.« V Il mondo Celtico prima e dopo la conquista romana, ur. D. Vitali in C. Goudineau, 115-44. Bologna: Museo Archeologico L. Fantini.

Filip, J. 1956. Keltové ve střední Evropě. Praga: Československé Akademie Vĕd.

Freeman, P. 1993. "Homer, Callimachus, Lucilius, and Virgil: The Classical Poet's View to the West." Proceedings of the Harvard Celtic Colloquium 13: $145-55$.

Furman, M. 2009. Kruhový šperk ako prameň archeologicky postihnutel'ného kroja, distribučných aktivit a mobility keltských komunit $v$ stredodunajskom priestore. Nitra: Slovenská Akadémia Vied.

Furman, M. 2012. »The Interpretative Value of Annular Ornaments for the study of Early Celtic Populations in the Middle Danube Area." V Iron Age Rites and Rituals in the Carpathian Basin, Proceedings of the international colloquium from Târgu Mureş, 7-9 October 2011, ur. S. Berecki, 27387. Târgu Mureş: Mega.

Furman, M. 2014. «Variabilita keltských kruhových garnitúr v stredoeurópskom priestore so zretel'om na použité suroviny." V Moravské křižovatky: Střední Podunají mezi pravěkem a historií, ur. J. Čižmárova, N. Venclová in G. Březinová, 493-514. Brno: Moravské zemské muzeum.

Galiniki, S. 2014. »The Multifaceted Encounter of Greeks and Celts.«V The Europe of Greece. Colonies and Coins from the Alpha Bank Collection, ur. D. Tsagkari, 294-301. Atene: The Alpha Bank.

Gebhard, R. 1989. Das Glasschmuck aus dem Oppidum von Manching: Die Ausgrabungen in Manching, Band 11. Stuttgart: Steiner.

Hodson, F. R. 1968. The La Tène Cemetery at Münsingen-Rain. Acta Bernensia V. Bern: Stämpfli.

Horváth, L. 1987. »The Surroundings of Keszthely." V Transdanubia 1 - Corpus of Celtic finds in Hungary, Vol. 1, ur. L. Horváth, M. Kelemen, A. Uszoki in É. Vadász, 63-178. Budimpešta: Akadémiai Kiadó.

Hunyady, I. 1942. Die Kelten im Karpatenbecken. Tafelband. Dissertationes panonicae II/18. Budimpešta: Pázmany Universität.

Kaenel, G. 2007. „Les mouvements de populations celtiques: aspects historiographiques et confrontations archéologiques."V La Gaule dans son contexte européen aux IVe et IIIe siècles avant notre ère: actes du XXVIIe Colloque international de l'Association française pour l'étude de l'âge du fer, Clermont-Ferrand, 29 mai-1er juin 2003, ur. C. Mennessier-Jouannet, A.-M. Adam in P.-Y. Milcent, 385-98. Lattes: Éd. de l'Association pour le développement de l'archéologie en Languedoc-Rousillon. 
Kavur, B., in M. Blečić Kavur 2018. „Celts on Their Way to the 'South': Once Again Discussing Some Finds from the Balkans."Folia Archaeologica Balkanica 4: 149-68.

Kavur, B., in M. Guštin 2011. "Contribution to Cchronology." V The Eastern Celts: The Communities between the Alps and the Black Sea, ur. M. Guštin in M. Jevtić, 129-30. Koper: Univerzitetna založba Annales.

Krämer, W. 1961. »Keltische Hohlbuckelringe vom Istmus von Korint.« Germania 39: 32-42.

Krämer, W. 1962. »Manching II.« Germania 40: 293-317.

Krämer, W. 1985. Die Grabfunde von Manching und die latènezeitlichen Flachgräber in Südbayern. Die Ausgrabungen in Manching 9. Stuttgart: Steiner.

Kruta, V. 1975. L'art Celtique en Bohême: les parures métalliques du Ve au IIe siècle avant notre ère. Pariz: $\mathrm{H}$. Champion.

Kruta, V. 2000 Les Celtes: Histoire et dictionnaire. Pariz: Robert Laffont.

Maier, F. 1973. »Keltische Altertümer in Griechenland.« Germania 51: 459-77.

Martin-Kilcher, S. 1973. "Zur Tracht- und Beigabensitte im keltischen Gräberfeld von Münsingen-Rain (Kt. Bern).«Zeitschrift für Schweizerische Archäologie und Kunstgeschichte 30: 26-39.

Masse, A. 2007. "La fabrication de la parure annulaire en bronze à oves creux du bassin des Karpates." V La Gaule dans son contexte européen aux IVe et IIIe siècles avant notre ère: actes du XXVIIe Colloque international de l'Association française pour l'étude de l'âge du fer, Clermont-Ferrand, 29 mai-1er juin 2003, ur. C. Mennessier-Jouannet, A-M. Adam in P-Y. Milcent, 301-8. Lattes: Association pour le développement de l'archéologie en Languedoc-Rousillon.

Masse, A., in M. Szabó 2005. "La parure annulaire en bronze à oves creux de la periode latènienne dans le bassin des Karpates." Communicationes Archaeologice Hungariae 2005: 213-25.

Megaw, J. V. S. 2004. "In the Footsteps of Brennos? Further Archaeological Evidence for Celts in the Balkans.«V Zwischen Karpaten und Ägäis. Neolithikum und Ältere Bronzezeit. Gedenkschrift für Viera NĕmejcováPavúková, ur. B. Hänsel in E. Studeniková, 93-107.

Mitchell, S. 2001. Anatolia: Land, Men, and Gods in Asia Minor: Vol. I. The Celts and their Impact on the Roman Rule. Oxford: Clarendon Press.

Németi, I. 1992. "Necropola Latène de la Pişcolt, jud. Satu Mare III.« ThracoDacica 13: 59-112. 
Papazoglu, F. 2007. Srednjobalkanska plemena u predrimsko doba: Tribali, Autarijati, Dardanci, Skordisci i Mezi. Beograd: Equilibrium.

Píč, J. L. 1902. Čechy na úsvitě dějin: na základě praehistorické sbírky musea království Českého a pramenů dějepisných. Praga: V Praze.

Ratimorská, P. 1981. »Keltské pohrebisko v Chotíne I. Západné Slovensko.« Vlastivedný zbornik Muzei západnoslovenskéhe kraja 8: 15-88.

Raubitschek, I. K. 1986. »Celts in Corinth." V Corinthica: Studies in Honor of Darrell A. Amyx, ur. M. A. Del Chiaro, 40-43. Columbia, MO: University of Missouri Press.

Raubitschek, I. K. 1998. Isthmia. The Metal Objects (1952-1989). Isthmia Vol. VII. Princeton, NJ: American School of Classical Studies at Athens.

Rawlings, L. 1996. „Celts, Spaniards, and Samnites: Warriors in a Soldier's War.« Bulletin of the Institute of Classical Studies Supplement 41 (S67): 81-95.

Rieckhoff, S., in J. Biel 2001. Die Kelten in Deutschland. Stuttgart: K. Theiss.

Rustoiu, A., in M. Egri 2010. »Danubian Kantharoi - Almost Three Decades Later." V Iron Age Communities in the Carpathian Basin: Proceedings of the International Colloquium from Târgu Mureş 9.-11. 10. 2009, ur. S. Berecki, 217-87. Cluj-Napoca: Mega.

Sankot, P. 2002. "Zur Problematik des Kunsthandwerkes und der Werkstattbeziehungen in Böhmen während der Früh- und Mittellatènezeit.« V Dürrnberg und Manching. Wirtschaftsarchäologie im ostkeltischen Raum. Kolloquien zur Vor- und Frühgeschichte, ur. C. Dobiat, S. Sievers in T. Stöllner, 331-48. Bonn: Habelt.

Schaaf, U. 1972a. »Ein keltisches Hohlbuckelring aus Kleinasien.« Germania 50: 94-97.

Schaaf, U. 1972b. »Zur tragweise keltischer Hohlbuckelringe.« Archäologisches Korrespondenzblatt 2: 155-58.

Schönfelder, M. 2007. »Zurück aus Griechenland - Spuren keltischer Söldner in Mitteleuropa.« Germania 85: 307-28.

Scott, M. 2014. Delphi: A History of the Center of the Ancient World. Princeton, NJ: Princeton University Press.

Szabó, M. 1968. "Zur Frage des keltischen Fundes von Isthmia." Acta Archaeologica Academiae Scientiarum Hungaricae 16: 173-79.

Szabó, M. 1971. »Une fibule celtique a Délos. Bulletin de la correspondence hellénique 95 (2): 503-14.

Szabó, M. 1972. »Kelta fibula Déloson.« Antik Tanulmányok 18: 37-45. 
Szabó, M. 1983. »Audoleon und die Anfänge der Ostkeltischen Münzprägung.« Alba Regia 20: 43-56.

Szabó, M. 1991. »Il mercenario.« V I Celti, ur. S. Moscati, 333-36. Milano: Bompiani.

Szabó, M. 1996. »Le monde celitque au III siècle av. J.-C.« Études celtiques 32: 11-31.

Szabó, M. 2000. »La Macédoine hellénistique et le monde celtique.«Ocnus 8: 287-295.

Szabó, M. 2012. "Isthmia, Griechenland.« V Lexikon zur Keltischen Archäologie, A-K, ur. S. Sievers, O. H. Urban in P. C. Ramsl, 840-41. Dunaj: Österreichischen Akademie der Wissenschaften.

Szabó, M. 2015. »Des 'riches' et des 'pauvres'. Sur la structure des Celtes orientaux à l'époque de l'expansion (VI ${ }^{\text {e}}-\mathrm{III}^{\mathrm{e}}$ siècles av. J.-C.)." V An der Grenze der Bronze- und Eisenzeit: Festschrift für Tibor Kemencei zum 75. Geburtstag, ur. I. Szathmári, 391-410. Budimpešta: Magyar Nemzeti Múzeum.

Szabó, M., in K. Tankó 2006. "Nécropole laténienne à Ludas-Varjú-Dűlő.» Acta Archaeologica Academiae Scientiarum Hungaricae 57 (4): 325-43.

Šašel Kos, M. 2005. Appian and Illyricum. Situla 43. Ljubljana: Narodni muzej Slovenije.

Taylor, T. 2001. »Believing the Ancients: Quantitative and Qualitative Dimensions of Slavery and the Slace Trade in Later Prehistory Eurasia." World Archaeology 3 (1): 27-43.

Theodossiev, N. 200o. North-Western Thrace from the Fifth to First Centuries $B C .$, British Archaeological Reports, International Series 859. Oxford: Archaeopress.

Theodossiev, N. 2005. "Celtic Settlement in North-Western Thrace During the Late Fourth and Third Centuries BC: Some Historical and Archaeological Notes."V Celts on the Margin: Studies in European Cultural Interaction 7th Century BC - 1 Century AD, Dedicated to Zenon Woźniak, ur. H. Dobrzańska, J. V. S. Megaw in P. Poleska, 85-92. Krakov: Institute of Archaeology and Ethnology of the Polish Academy of Sciences.

Vadász, É. 1987. »Komárom County.«V Transdanubia 1 - Corpus of Celtic finds in Hungary, Vol. 1, ur. L. Horváth, M. Kelemen, A. Uszoki in É. Vadász, 231-48. Budimpešta: Akadémiai Kiadó.

Verger, S. 2003. »Des objects dans les sanctuaires archaïques de Grèce, de Sicile et d'Italie." Comptes-rendus des séances de l'Académie des Inscriptions et Belles-Lettres 147 (1): 525-573.

Vokotopoulou, J. 1996. Führer durch das Archäologische Museum Thessaloniki. Atene: Kapon. 
Waldhauser, J. 1978. Das Keltische Gräberfeld bei Jenišưv újezd in Böhmen. Archeologický výzkum v severních Čechách 6-7. Teplice: Regionální muzeum Teplice.

Zaninović, M. 2003. »Područje Neretve i srednjojadransko otočje.« Izdanja Hrvatskog arheološkog društva 22: 277-87.

Zirra, V. 1971. "Stand der Forschung der Keltischen Spätlatènezeit in Rumänien.«Archeologické rozhledy 23: 529-603.

\section{Summary}

\section{Contact of Civilization}

History of interpretations of Celtic jewelry from Isthmia

One of the main topics of prehistoric archaeology in the last 50 years has been the discussion of the chronology of contacts between the prehistoric communities of Europe and the civilizations of the Eastern Mediterranean - especially the Greek states and ancient Macedonia. This process was mostly seen as a one-way flow of goods and information towards the north, and only a few discoveries of objects of Celtic provenance pointed out that it was, in fact, a cooperation and communication of relatively equal interlocutors. The discovery of Celtic ankle rings from the vicinity of Poseidon's Sanctuary in Isthmia was one of the few in the Greek world with a known clear stratigraphic and chronological context. The interpretation of its chronology has sparked heated debate in the decades since its discovery. The proposed Mediterranean and Central European chronology of objects did not appear to match - they were discovered together with pottery from the late 4 th century BC, while in Central Europe, their presumable place of origin, they were dated into the middle of the 3 rd century BC. Having problems with conceptually explaining their presence in Isthmia most authors have taken refuge in the haven of historical determinism and attributed the find to the period after the Celtic raid on Delphi in 279 BC when the Celtic presence was indisputably attested. Such an approach further complicated the explanation of the contact since it ignored the dating of their context of discovery - detailed archaeological results were overrun by a superficial historical explanation. And even today, almost a century after their discovery, only a handful of authors dare to interpret them as one of the main illustrations of contact of civilizations and as an illustration of two major problems - historical determinism in classical archaeology on one and chronological problems of prehistoric archaeology on the other side. 